\title{
Pengaruh Likuiditas, Leverage, dan Profitabilitas terhadap Nilai Perusahaan pada Subsektor Makanan dan Minuman yang Terdaftar di BEI 2015-2018
}

\author{
ANGGUN WIMIDHATI \\ IIN INDARTI \\ WENNY ANA ADNANTY \\ Sekolah Tinggi Ilmu Ekonomi Widya Manggala \\ Jalan Sriwijaya No. 32 \& 36 Semarang 504242 \\ Email : anggunwimidhati@gmail.com
}

\section{Diterima 25 Agustus 2021; disetujui 3 September 2021;}

\begin{abstract}
The purpose of this study was to analyze the effect of liquidity, leverage, and profitability on firm value of food and beverage companies listed on the Indonesia Stock Exchange period 2014-2018. The population were 72 and the sample were 40 companies. This study used the technique of classical assumption test and multiple linear regression analysis. Partial results of research showed that liquidity did not affect firm value, leverage had a significant positive effect on firm value, profitability had significant positive effect on firm value.
\end{abstract}

Keywords : The value of the company, Liquidity, Leverage, Profitability

\section{PENDAHULUAN}

Persaingan usaha saat ini yang terjadi makin ketat hal itu membuat setiap perusahaan harus mempunyai strategi bisnis yang baik untuk meningkatkan kinerja supaya tercapai tujuan perusahaan, salah satu cara untuk mengukur keberhasilannya dilihat dari manajer perusahaan yang harus bisa melakukan tanggung jawabnya secara lebih efektif dan efesien dalam mengambil setiap keputusan agar dapat menjaga dan mempertahankan stabilitas perusahaan dalam persaingan bisnis.

Nilai perusahaan merupakan persepsi investor terhadap tingkat keberhasilan perusahaan, yang sering dikaitkan dengan harga saham, semakin tinggi harga saham perusahaan mencerminkan nilai perusahaan tersebut makin meningkat (Hery, 2017). Salah satu upaya dalam meningkatkan nilai perusahaan yaitu dengan meningkatkan sistem manajemen dalam hal kreatifitas produk yang dipasarkan, menawarkan harga produk yang kompetitif dan memberikan layanan yang baik bagi konsumen. Dalam penelitian ini, nilai perusahaan diukur dengan menggunakan price book value (PBV), adalah rasio perbandingan harga saham dan nilai buku ekuitas perusahaan, yang mengukur nilai yang diberikan kepada manajemen dan organisasi sebagai sebuah perusahaan yang tumbuh, PBV sering digunakan sebagai acuan dalam menentukan nilai suatu saham relative terhadap harga pasarnya (Hery, 2017). Semakin rendah PBV berarti semakin rendah harga saham relatif terhadap nilai bukunya, sebaliknya semakin tinggi PBV maka semakin tinggi harga saham relatif terhadap nilai bukunya, hal ini mengindikasikan bahwa perusahaan yang bertumbuh dapat dinilai dari harga pasar sahamnya (Heri, 2017). 
Likuiditas adalah rasio yang menggambarkan kemampuan perusahaan dalam memenuhi kewajiban utang jangka pendek (Kasmir, 2008). Alat ukur likuiditas Current Ratio (CR) merupakan rasio untuk mengukur kemampuan perusahaan dalam membayar kewajiban jangka pendek atau utang yang segera jatuh tempo pada saat ditagih secara keseluruhan. Likuiditas pada aspek Current Ratio (CR) dalam meningkatkan nilai perusahaan. Rasio ini memberikan gambaran tentang kemampuan perusahaan dalam memenuhi kewajibankewajiban jangka pendeknya, semakin besar prosentase current ratio (CR), maka perusahaan memiliki tingkat likuidasi yang baik sehingga akan memberikan persepsi positif terhadap perusahaan serta akan meningkatkan nilai perusahaan dimata investor (Raja dan Catur, 2016). Leverage dapat dipahami sebagai penaksir dari resiko yang melekat pada perusahaan, pada umumnya investor menghindari perusahaan yang memiliki leverage yang tinggi karena semakin tinggi rasio leverage maka semakin tinggi pula resiko yang akan dibebankan, khususnya apabila perusahaan tidak dapat memenuhi kewajibannya secara tepat waktu (Hery, 2017). Rasio leverage diukur Debt to Equity Ratio (DER) merupakan rasio yang digunakan untuk menilai utang dengan ekuitas, rasio ini dicari dengan cara membandingkan antara seluruh utang, termasuk utang lancar dengan seluruh ekuitas (Kasmir, 2008).

Profitabilitas adalah kemampuan perusahaan untuk mendapatkan keuntungan dalam suatu periode tertentu, apabila profitabilitas perusahaan baik maka para kreditor dan investor akan melihat sejauh mana perusahaan dapat menghasilkan laba dari penjualan dan investasi, semakin baik kinerja perusahaan akan meningkatkan nilai perusahaan, semakin tinggi rasio profitabilitas mencerminkan tingkat pengembalian investasi yang tinggi juga bagi para pemegang saham, sehingga akan menarik perhatian investor untuk menanamkan modalnya (Hery, 2017).
Profitabilitas dapat diukur dengan Return on Equity (ROE) rasio untuk mengukur laba bersih sesudah pajak dengan modal sendiri, rasio ini menunjukkan efisiensi penggunaan modal sendiri, semakin tinggi rasio ini semakin baik artinya posisi pemilik perusahaan semakin kuat, demikian pula sebaliknya (Kasmir,2008). Nilai perusahaan mencerminkan sejauh mana suatu perusahaan diakui oleh publik, semakin baik nama perusahaan di mata publik maka nilai saham perusahaan akan tinggi sehingga akan membuat para investor untuk menanamkan saham ke perusahaan tersebut.

Penelitian ini dilakukan pada perusahaan sektor makanan dan minuman karena pertumbuhan perusahaan makanan dan minuman di Indonesia makin pesat, berdampak terhadap nilai perusahaan makanan dan minuman. Investasi saham di perusahaan makanan dan minuman, sektor ini dipilih karena memegang peran penting dalam kebutuhan masyarakat di Indonesia. Peningkatan jumlah penduduk di Indonesia memberikan dampak pada meningkatnya permintaan kebutuhan masyarakat terhadap makanan dan minuman. Berikut adalah data nilai perusahaan sub sektor makanan dan minuman yang mengalami fluktuaktif atau tidak seimbang.

Penurunan harga saham PT. Prashida Aneka Niaga, Tbk dari tahun 2011 hingga 2015, diperkirakan terjadi karena krisis ekonomi yang terjadi pada tahun sebelumnya dan perubahan laporan informasi pada arus kas. Pada tahun 2012 PT. Prashida Aneka Niaga, Tbk mengalami penurunan laba sebesar 37,48\%, akibat besarnya beban pokok penjualan dan biaya operasi dibandingkan dengan perolehan penjualan (www.iqplus.info).

Krisis ekonomi global yang terjadi di tahun 2008 berdampak terhadap pasar modal Indonesia tercermin dari terkoreksi turunnya harga saham hingga 40 - 60 persen dari posisi awal tahun 2008 . 
Tabel I

Nilai Perusahaan Sub Sektor Makanan dan Minuman yang Terdaftar di BEI Tahun 2015-2018

\begin{tabular}{cccccc}
\hline No & \multirow{2}{*}{$\begin{array}{c}\text { Nama } \\
\text { Perusahaan }\end{array}$} & \multicolumn{5}{c}{ Tahun } \\
\cline { 3 - 6 } & & 2015 & 2016 & 2017 & 2018 \\
\hline 1 & ALTO & 1.4 & 1.5 & 2.02 & 2.26 \\
2 & CEKA & 0.31 & 0.9 & 0.84 & 0.83 \\
3 & DLTA & 4.9 & 3.95 & 3.21 & 3.42 \\
4 & ICBP & 4.79 & 5.4 & 5.1 & 5.36 \\
5 & INDF & 1.05 & 1.58 & 1.43 & 1.31 \\
6 & MLBI & 22.54 & 30.1 & 27.05 & 28.8 \\
7 & PSDN & 0.54 & 0.68 & 1.23 & 1.13 \\
8 & ROTI & 5.38 & 5.61 & 2.79 & 2.54 \\
9 & ULTJ & 4.07 & 3.78 & 3.55 & 3.26 \\
10 & SKBM & 1.5 & 1.62 & 1.2 & 1.15 \\
\hline & Rata-Rata & 4.648 & 5.512 & 4.842 & 5.006 \\
\hline
\end{tabular}

Kondisi tersebut secara harfiah mempengaruhi nilai perusahaan karena nilai perusahaan itu sendiri jika diamati melalui kemakmuran pemegang saham yang dapat diukur melalui harga saham perusahaan di pasar modal. (Kompas, 25 November 2008).

Putri dan Dudi (2019) menyatakan bahwa profitabilitas berpengaruh positif dan signifikan terhadap nilai perusahaan. Sedangkan penelitian Khumairoh dan Henny (2015) menunjukkan hasil yang berbeda bahwa profitabilitas signifikan tidak berpengaruh terhadap nilai perusahaan.

Rumusan Masalah. Apakah likuiditas, leverage, dan profitabilitas berpengaruh terhadap nilai perusahaan pada sub sektor makanan dan minuman.

Tujuan Penulisan. Untuk menganalisis pengaruh likuiditas, leverage dan profitabilitas terhadap nilai perusahaan secara parsial maupun simultan.

\section{TINJAUAN TEORETIS}

Nilai Perusahaan. Pada umumnya tujuan didirikannya suatu perusahaan adalah untuk mendapatkan laba sebesar-besarnya, karena dengan laba yang besar diharapkan mampu memakmurkan parapemegang saham dan menarik minat investor untuk berinvesatsi pada perusahaan tersebut (Aniela dkk,
2017). Semakin tinggi harga saham berarti semakin tinggi tingkat pengembalian kepada investor dan itu berarti semakin tinggi juga nilai perusahaan terkait dengan tujuan dari perusahaan itu sendiri, yaitu untuk memaksimalkan kemakmuran pemegang saham (Gulton dan Syarif, 2008).

Nilai perusahaan merupakan harga yang bersedia dibayar oleh investor apabila perusahaan tersebut dijual (Prasetyorini, 2013). Dalam upaya meningkatkan nilai perusahaan manajemen melakukan berbagai cara agar mensejahterahkan para pemegang saham. Salah satunya dengan memaksimalkan nilai perusahaan menjadi sangat penting artinya, karena dengan memaksimalkan nilai perusahaan berarti juga memaksimalkan kemakmuran bagi pemegang saham yang merupakan tujuan utama perusahaan (Hery, 2017).

Likuiditas. Likuiditas merupakan suatu indikator mengenai kemampuan perusahaan untuk membayar semua kewajiban finansial jangka pendek pada saat jatuh tempo dengan menggunakan aktiva lancar yang tersedia (Syamsuddin, 2013). Penyebab utama dari ketidakmampuan perusahaan untuk membayar kewajibannya tersebut karena kelalaian manajemen dalam menjalankan usahanya. Nilai current ratio (CR) dan quick ratio (QR) yang semakin tinggi menunjukkan 
perusahaan memiliki tingkat likuidasi yang baik sehingga dapat meningkatkan nilai perusahaan di mata investor serta memberikan persepsi yang positif terhadap kondisi perusahaan (I Putu dan I Gde, 2019).

Leverage. Leverage merupakan rasio yang mengukur seberapa jauh perusahaan dibiayai oleh kewajiban atau pihak luar dengan kemampuan perusahaan yang digambarkan oleh ekuitas (Harahap, 2009). Leverage merupakan suatu alat penting dalam pengukuran efektivitas penggunaan utang perusahaan, konsep leverage ini penting bagi investor dalam membuat pertimbangan penilaian saham karena para investor umumnya cenderung menghindari resiko (Prasetyorini, 2013).

Profitabilitas. Profitabilitas yaitu kemampuan perusahaan untuk memperoleh laba dari modal yang digunakan untuk menghasilkan laba tersebut (Harjito dan Martono, 2011). Rasio profitabilitas bisa digunakan untuk mengukur tingkat kinerja manajemen dalam suatu perusahaan. Kinerja yang baik akan ditunjukkan lewat keberhasilan manajemen dalam menghasilkan laba yang maksimal bagi perusahaan (Hery, 2017). Dengan demikian setiap perusahaan pasti akan berusaha meningkatkan profitabilitasnya, karena semakin tinggi profitabalitas suatu perusahaan maka semakin tinggi pula keuntungan yang didapat, sehingga kelangsungan perusahaan dan para investorpun akan terjamin.

Kerangka Teoritis. Berdasarkan hasil dari penelitian terdahulu mengenai pengaruh likuiditas, leverage dan profitabilitas terhadap nilai perusahaan, maka kerangka pemikiran taoritis yang mendasari penelitian ini digambarkan dalam sebuah model seperti pada berikut ini:
H1 : Likuiditas berpengaruh positif terhadap nilai perusahaan pada sub sektor makanan dan minuman di Bursa Efek Indonesia 2015-2018.

$\mathrm{H} 2$ : Leverage berpengaruh positif terhadap nilai perusahaan pada sub sektor makanan dan minuman di Bursa Efek Indonesia 2015-2018.

H3 : Profitabilitas berpengaruh positif terhadap nilai perusahaan pada sub sektor makanan dan minuman di Bursa Efek Indonesia 2015-2018.

H4 : Terdapat pengaruh secara simultan antara likuiditas, leverage, dan profitabilitas terhadap nilai perusahaan pada sub sektor makanan dan minuman di Bursa Efek Indonesia 2015-2018.

\section{METODOLOGI PENELITIAN}

Jenis Penelitian. Jenis penelitian yang digunakan dalam penelitian ini adalah penelitian kausal komparatif yaitu tipe penelitian dengan karakteristik masalah berupa hubungan sebab akibat antara dua variabel atau lebih (Elianah:2014). Peneliti dapat mengidentifikasi fakta atau peristiwa tersebut sebagai variabel yang dipengaruhi (variable dependen) dan melakukan penyelidikan terhadap variabel-variabel yang mempengaruhi (variabel independent).

\section{Definisi Operasional}

Nilai Perusahaan (Y). nilai perusahaan, (Rinnayaetal, 2016 dalam Hery, 2017) nilai perusahaan merupakan kondisi tertentu yang telah dicapai oleh suatu perusahaan sebagai gambaran dari kepercayaan masyarakat terhadap perusahaan setelah melalui suatu proses kegiatan selama beberapa tahun, yaitu mulai dari perusahaan tersebut didirikan sampai dengan saat ini. Berikut rumus nilai perusahaan :

Price to Book Value $=\frac{\text { Harga per Lembar Saham }}{\text { Nilai Buku per Lembar Saham }}$ 
Tabel 2

Penelitian Terdahulu

\begin{tabular}{|c|c|c|c|}
\hline No & Penelitian & Variabel & Hasil Penelitian \\
\hline 1 & Fakhrana dkk 2019 & $\begin{array}{l}\text { Variabel Dependen : } \\
\text { Nilai Perusahaan } \\
\text { Variabel Independen : } \\
\text { Profitabilitas, } \\
\text { Likuiditas, Leverage }\end{array}$ & $\begin{array}{l}\text { Hasil penelitian ini menjelaskan bahwa } \\
\text { likuiditas dan profitabilitas ber- } \\
\text { pengaruh positif terhadap nilai peru- } \\
\text { sahaan, sedangkan leverage tidak } \\
\text { berpengaruh terhadap nilai perusahaan }\end{array}$ \\
\hline 2 & $\begin{array}{l}\text { Putri dan Dr. Dudi } \\
\text { (2019) }\end{array}$ & $\begin{array}{l}\text { Variabel Dependen : } \\
\text { Nilai Perusahaan } \\
\text { Variabel Independen : } \\
\text { Profitabilitas, } \\
\text { Likuiditas, Solvabilitas }\end{array}$ & $\begin{array}{l}\text { Hasil penelitian ini menjelaskan bahwa } \\
\text { likuiditas berpengaruh negatif dan } \\
\text { signifikan terhadap nilai perusahaan, } \\
\text { sedangkan profitabilitas dan leverage } \\
\text { berpengaruh positif dan signifikan } \\
\text { terhadap nilai perusahaan. }\end{array}$ \\
\hline 3 & $\begin{array}{l}\text { I Putu dan I Gde } \\
\text { (2019) }\end{array}$ & $\begin{array}{l}\text { Variabel Dependen : } \\
\text { Nilai Perusahaan } \\
\text { Variabel Independen : } \\
\text { Profitabilitas, Leverage, } \\
\text { Likuiditas }\end{array}$ & $\begin{array}{l}\text { Hasil penelitian ini menjelaskan bahwa } \\
\text { leverage tidak berpengaruh signifikan } \\
\text { terhadap nilai perusahaan, sedangkan } \\
\text { profitabilitas dan likuiditas } \\
\text { berpengaruh positif signifikan terhadap } \\
\text { nilai perusahaan. }\end{array}$ \\
\hline 4 & $\begin{array}{l}\text { Raja dan Catur } \\
(2016)\end{array}$ & $\begin{array}{l}\text { Variabel Dependen : } \\
\text { Nilai Perusahaan } \\
\text { Variabel Independen : } \\
\text { Likuiditas, Leverage, } \\
\text { Profitabilitas }\end{array}$ & $\begin{array}{l}\text { Hasil penelitian ini menjelaskan bahwa } \\
\text { likuiditas dan leverage tidak } \\
\text { berpengaruh signifikan terhadap nilai } \\
\text { perusahaan, sedangkan profitabilitas } \\
\text { berpengaruh signifikan terhadap nilai } \\
\text { perusahaan }\end{array}$ \\
\hline 5 & Irma dkk (2018) & $\begin{array}{l}\text { Variabel Dependen : } \\
\text { Nilai Perusahaan } \\
\text { Variabel Independen : } \\
\text { Likuiditas, } \\
\text { Profitabilitas, Leverage }\end{array}$ & $\begin{array}{l}\text { Hasil penelitian ini menjelaskan bahwa } \\
\text { likuiditas tidak signifikan terhadap nilai } \\
\text { perusahaan, sedangkan prifitabilitas } \\
\text { dan solvabilitas berpengaruh signifikan } \\
\text { terhadap nilai perusahaan. }\end{array}$ \\
\hline
\end{tabular}

\section{Gambar 1}

Kerangka Pemikiran Teoritis

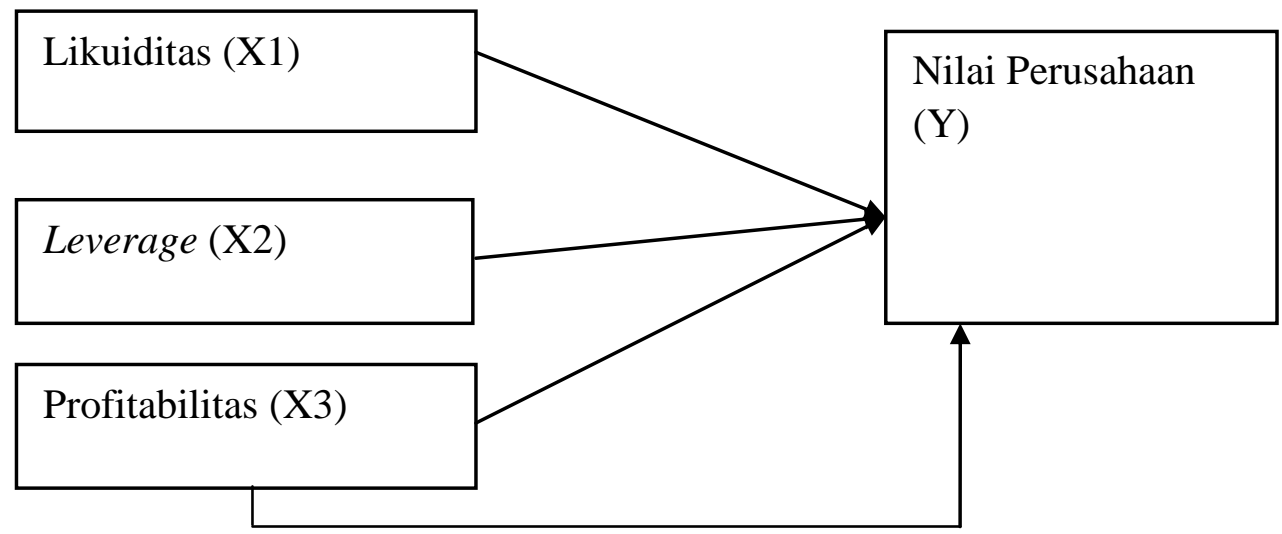

Sumber : Raja dan Wulan (2016) 
Indikator Price to Book Value (PBV) adalah :

1. Harga per lembar saham = Harga per lembar saham perusahaan

2. Nilai buku per lembar saham = Nilai buku per lembar saham.

Likuiditas (X1). Likuiditas merupakan rasio yang menggambarkan kemampuan perusahaan dalam memenuhi kewajiban (utang) jangka pendek (Kasmir, 2008). Berikut rumus Likuiditas :

$$
\text { Current Ratio }=\frac{\text { Current Asset }}{\text { Current Liabilities }} \times 100 \%
$$

Indikator Current Ratio (CR) adalah :

1. Current Asset = Aktiva lancer

2. Current Liabilities $=$ Hutang lancer

Leverage (X3). (Kasmir, 2008) Rasio solvabilitas atau leverage ratio merupakan rasio yang di gunakan untuk mengukur sejauh mana aktiva perusahaan dibiayai dengan utang, artinya berapa besar beban utang yang ditanggung perusahaan dibandingkan dengan aktiva. Berikut rumus leverage:

Debt to Equity Ratio $=\frac{\text { Total Liabilities }}{\text { Total Equity }} \times 100$

Indikator Debt to Equity Ratio (DER) adalah :

1. Total Liabilities $=$ Total hutan

2. Total Equity = Total modal sendiri

Profitabilitas (X3). Profitabilitas merupakan rasio untuk menilai kemampuan perusahaan dalam mencari keuntungan (Kasmir, 2008:196). Berikut rumus profitabilitas :

$$
R O E=\frac{\text { Earning after Interest and Tax }}{\text { Total Equity }} \times 100 \%
$$

Indikator ROE :
1. Earning After Interest and Tax= Laba dari kegiatan operasional setelah pajak

2. Total Equity = Ekuitas perusahaan

Populasi dan Sampel. Populasi dalam penelitian ini adalah seluruh perusahaan sub sektor makanan dan minuman yang tercatat di Bursa Efek Indonesia pada tahun 2015-2018 berjumlah 18 perusahaan, Sampel yang dipilih dari 18 perusahaan yaitu ada 10 perusahaan karena di lihat dari laporan keuangan yang dilaporkan secara berturut-turut selama empat tahun.

Teknik Pengambilan Sampel. Teknik pengambilan sampel dalam penelitian ini adalah dengan menggunakan metode purposive sampling, dengan metode judgement yaitu tipe pengambilan sampel secara tidak acak yang informasinya diperoleh dengan menggunakan pertimbangan tertentu (umumnya disesuaikan dengan tujuan dan masalah penelitian) (Indrianto dan Supomo, 1999).

Jenis Data. Jenis data yang digunakan dalam penelitian adalah data dokumenter, yaitu data yang memuat apa dan kapan suatu kejadian atau transaksi, serta siapa yang terlibat dalam suatu kejadian (Indrianto dan Supomo, 1999). Penelitian ini berupa data yang diambil dari laporan keuangan tahunan perusahaan Sub makanan dan minuman 2015-2018.

Sumber Data. Data penelitian ini data yang digunakan adalah data sekunder yaitu data-data perusahaan yang terdaftar di Bursa Efek Indonesia (BEI) tahun 20152018.

Teknik Pengumpulan Data. Teknik pengumpulan data dalam penelitian ini menggunakan metode dokumentasi, yaitu pengumpulan dilakukan dengan mengumpulkan semua data sekunder yang telah dipublikasikan oleh Bursa Efek Indonesia 2015-2018.

Tehnik Analisis Data. Penelitian ini menggunakan pengujian asumsi klasik yang terdiri dari uji normalitas, uji autokorelasi, uji heteroskedasitas, uji multikolinieritas, dan uji regresi linear berganda, 
setelah uji asumsi klasik dapat dilanjut uji hipotesis.

\section{HASIL DAN PEMBAHASAN}

Berdasarkan tabel 1 variabel nilai perusahaan yang diproksikan dengan PBV memiliki nilai minimum sebesar 0,31 PT Wilmar Cahaya Indonesia Tbk (2015), nilai maksimum sebesar 30,17 PT Multi Bintang 2016. CR memiliki nilai minimum sebesar 0,58 PT Multi Bintang (2015), nilai maksimum sebesar 8,64 PT Delta Djakarta Tbk (2017). DER memiliki nilai minimum sebesar 0,16 PT Ultrajaya Milk Industry \& Trading Company Tbk (2018), nilai maksimum sebesar 1,87 PT Prasidha Aneka Niaga Tbk (2018). ROE memiliki nilai minimum sebesar -0,19 PT Prasidha Aneka Niaga Tbk (2018), nilai maksimum sebesar 1,24 PT Multi Bintang (2017).

Berdasarkan tabel 4 maka dapat dihasilkan output SPSS diperoleh hasil $t$ hitung $-0,056$ dengan nilai signifikan sebesar 0,956. Karena t hitung $-0,056<\mathrm{t}$ tabel 2,028 dan nilai signifikannya 0,956 yang lebih besar dari tingkat signifikan 0,05 maka kesimpulan, maka Ho diterima dan Ha ditolak artinya bahwa variabel likuiditas tidak berpengaruh terhadap nilai perusahaan.

- Dari hasil output SPSS diperoleh hasil t hitung 2,77 dengan nilai signifikan sebesar 0,009. Karena t hitung 2,77 > t tabel 2,028 dan nilai signifikannya 0,009 yang lebih kecil dari tingkat signifikan $0,05(\alpha)$ maka kesimpulan, maka Ho ditolak dan $\mathrm{Ha}$ diterima artinya bahwa variabel leverage berpengaruh positif signifikan terhadap nilai perusahaan.

- Dari hasil output SPSS diperoleh hasil t hitung 19,426 dengan nilai signifikan sebesar 0,000. Karena t hitung 19.426 $>\mathrm{t}$ tabel 2,028 dan hasil signifikannya 0,000 yang lebih kecil dari tingkat signifikan $0,05(\alpha)$

Tabel 3

Descriptive Statistics

\begin{tabular}{cccccc}
\hline & N & Minimum & Maximum & Mean & Std. Deviation \\
\hline PBV & 40 &, 31 & 30,17 & 5,0367 & 7,68945 \\
CR & 40 &, 58 & 8,64 & 2,5153 & 2,05333 \\
DER & 40 &, 16 & 1,87 &, 9015 &, 55084 \\
ROE & 40 &,- 19 & 1,24 &, 1924 &, 31735 \\
Valid N & 40 & & & & \\
(listwise) & & & & & \\
\hline
\end{tabular}

Sumber : Data sekunder yang diolah SPSS 21

Tabel 4

Hasil Uji Regresi

\begin{tabular}{|c|c|c|c|c|c|c|}
\hline \multirow{2}{*}{\multicolumn{2}{|c|}{ Model }} & \multicolumn{2}{|c|}{$\begin{array}{l}\text { Unstandardized } \\
\text { Coefficients }\end{array}$} & \multirow{2}{*}{$\begin{array}{c}\begin{array}{c}\text { Standardized } \\
\text { Coefficients }\end{array} \\
\text { Beta }\end{array}$} & \multirow[t]{2}{*}{$\mathrm{T}$} & \multirow[t]{2}{*}{ Sig. } \\
\hline & & $\mathrm{B}$ & $\begin{array}{c}\text { Std. } \\
\text { Error }\end{array}$ & & & \\
\hline 1 & $\begin{array}{c}\text { (Consta } \\
\text { nt) }\end{array}$ & $-1,748$ & 1,556 & & $-1,123$ & ,269 \\
\hline & CR &,- 015 & ,275 &,- 004 &,- 056 & 956 \\
\hline & DER & 2,862 & 1,033 & ,205 & 2,770 & ,009 \\
\hline & ROE & 22,061 & 1,136 & ,910 & 19,426 & ,000 \\
\hline
\end{tabular}

Sumber: Data sekunder yang diolah oleh SPSS 21 
Maka kesimpulan, maka Ho ditolak dan $\mathrm{Ha}$ diterima artinya bahwa variabel profitabilitas berpengaruh positif signifikan terhadap nilai perusahaan.

Berdasarkan tabel 5 diperoleh nilai $\mathrm{F}$ hitung sebesar 143,992 dengan nilai signifikan sebesar 0,000 , nilai $\mathrm{F}$ hitung $(143,992)>F$ tabel $(2,87)$, maka Ho ditolak dan $\mathrm{Ha}$ diterima yang berarti, secara simultan variabel (likuiditas, leverage dan profitabilitas) berpengaruh positif signifikan terhadap nilai perusahaan.

Besarnya nilai adjusted $\mathrm{R}^{2}$ sebesar 0,917 yang artinya variabel dependen nilai perusahaan dapat dijelaskan oleh variabilitas independent likuiditas, leverage dan profitabilitas yaitu sebesar $91,7 \%$, sedangakan sisanya $8,3 \%$ dijelaskan oleh sebab-sebab lain diluar variabel lain yang tidak dimasukkan dalam model regresi. Variabilitas $8,3 \%$ kemungkinan dapat disebabkan oleh variabel yang tidak dipakai dalam penelitian ini, salah satu contohnya dari kerangka pemikiran Fakhrana, dkk, (2019) yaitu pengaruh profitabilitas, likuiditas, leverage, kebijakan deviden dan ukuran perusahaan terhadap nilai perusahaan.

Pengaruh Likuiditas (X1) Terhadap Nilai Perusahaan. Berdasarkan variabel likuiditas nilai t hitung sebesar -0,056 dan nilai $\mathrm{t}$ tabel sebesar 2,028, yang berarti nilai t hitung lebih kecil dari nilai t tabel ($0,056<2,028)$ dan nilai signifikannya sebesar 0,956 , artinya nilai signifikan ini lebih besar dari 0,05 (0,956>0,05), maka dapat disimpulkan $\mathrm{Ha}$ ditolak dan $\mathrm{Ho}$ diterima. Hasil penelitian ini menunjukkan bahwa likuiditas tidak berpengaruh

Tabel 5

Hasil Uji F

\begin{tabular}{ccccccc}
\hline & \multicolumn{7}{c}{ ANOVA $^{\text {a }}$} \\
\hline & Model & Sum of & Df & Mean & F & Sig. \\
& Squares & & Square & & \\
\hline 1 & Regression & 2128,585 & 3 & 709,528 & 143,992 &, $000^{\mathrm{b}}$ \\
& Residual & 177,392 & 36 & 4,928 & & \\
& Total & 2305,977 & 39 & & \\
& \multicolumn{7}{c}{ a. Dependent Variable: PBV } \\
\hline
\end{tabular}

b. Predictors: (Constant), ROE, CR, DER

Sumber : Data sekunder yang diolah SPSS 21

Tabel 6

Hasil Uji Determinan ( $\mathbf{j j i} \mathbf{R}^{\mathbf{2}}$ )

Model Summary ${ }^{b}$

\begin{tabular}{lllll}
\hline Model & $\mathrm{R}$ & $\begin{array}{l}\mathrm{R} \\
\text { Square }\end{array}$ & $\begin{array}{l}\text { Adjusted } \\
\mathrm{R} \text { Square }\end{array}$ & $\begin{array}{l}\text { Std. } \\
\text { Error } \\
\text { the } \\
\text { Estimate }\end{array}$ \\
\hline 1 & \multicolumn{5}{c}{$\begin{array}{l}\text { Durbin } \\
\text { Watson }\end{array}$} \\
\hline a. Predictors: (Constant), ROE, CR, DER \\
b. Dependent Variable: PBV
\end{tabular}

Sumber : Data sekunder yang di olah SPSS 21 
terhadap nilai perusahaan karena perusahaan yang menjaga rasio likuiditas yang tinggi cenderung menghasilkan pendapatan yang lebih ditahan bukannya membayar uang tunai untuk memenuhi biaya investasi baru atau membayar kewajiban, sehingga dalam penelitian ini likuiditas tidak berpengaruh terhadap nilai perusahaan.

Likuiditas dapat dikatakan sebagai salah satu faktor untuk mengukur kemampuan perusahaan membayar kewajiban yang harus diselesaikan, hal tersebut akan memberikan dampak besar pada nilai perusahaan dihadapan investor dalam mengambil keputusan. Menurut (Sofiana, 2010) tingkat likuiditas dapat dilihat dari dua arah, suatu kesehatan perusahaan dilihat dari tingginya likuiditas yang dimiliki karena hal tersebut dinilai akan mempengaruhi tingkat pengungkapan. Hal tersebut menjadi harapan bahwa perusahaan yang mempunyai tingkat likuiditas tinggi akan lebih memenuhi kelengkapan dalam pengungkapan laporan keuangannya (Hanny dan Chariri, 2007). Jika perusahaan mampu memenuhi kewajiban jangka pendek tidak menjamin nilai perusahaan akan naik, artinya pembentukan likuiditas yang berlebihan tidak akan bagus, karena akan berakibat dana untuk investasi dalam meng-hasilkan profit berkurang (Putri dan Dudi, 2019). Dapat diketahui juga bahwa hutang jangka pendek bagi perusahaan sangatlah perlu, karena semakin besar perusahaan memiliki hutang jangka pendek, berarti bisa dikatakan bahwa kreditur percaya pada perusahaan tersebut adalah perusahaan yang sehat. Ketika perusahaan memiliki likuiditas yang rendah, akan membangun persepsi investor, sehingga akan berpengaruh terhadap tingginya nilai perusahaan.

Penelitian ini didukung oleh Sukarya dan Baskara (2019) yang menjelaskan bahwa likuiditas berpengaruh positif signifikan terhadap nilai perusahaan. Sama halnya juga dengan penelitian Fakhrana. Dkk (2019) menjelaskan bahwa likuiditas berpengaruh positif terhadap nilai perusahaan.
Penelitian ini juga mendukung hasil penelitian dari Nurhayati (2013) menyimpulkan bahwa rasio likuiditas tidak berpengaruh terhadap nilai perusahaan. Sama dengan hasil penelitian dari Raja dan Catur (2016) menyimpulkan bahwa likuiditas berpengaruh negatif terhadap nilai perusahaan, yang berarti likuiditas di dalam perusahaan dapat menurunkan nilai perusahaan tersebut.

Pengaruh Leverage (X2) Terhadap Nilai Perusahaan. Berdasarkan variabel leverage nilai $\mathrm{t}$ hitung sebesar 2,770 dan nilai t tabel sebesar 2,028 yang berarti nilai $t$ hitung lebih besar dari nilai $\mathrm{t}$ tabel $(2,770>$ 2,028 ) dan nilai signifikannya sebesar 0,009 , artinya nilai signifikan ini lebih kecil dari $0,05(0,009<0,05)$, maka dapat disimpulkan Ha diterima Ho ditolak. Hasil penelitian ini menunjukkan bahwa leverage berpengaruh positif signifikan terhadap nilai perusahaan.

Leverage merupakan rasio yang digunakan untuk mengukur sejauh mana asset perusahaan dibiayai dengan utang (Kasmir, 2016). Perusahaan yang mempunyai tingkat leverage tinggi mempunyai kemampuan berupa menanggung biaya pengawasan (monitoring cost) yang tinggi. Apabila perusahaan mempunyai leverage yang tinggi maka potensi perusahaan untuk memenuhi pengungkapan laporan keuangan juga akan semakin meningkat. Menurut Sudarmadji dan Sularto (2007) menyatakan bahwa pengawasan dapat dilakukan dengan menilai luasnya pengungkapan informasi keuangan yang dipublikasikan oleh perusahaan.

Leverage dalam perusahaan dapat meningkatkan nilai perusahaan, hal ini menunjukkan bahwa dengan adanya peningkatan utang atau semakin besar hutang perusahaan maka semakin besar nilai aktiva perusahaan yang dibiayai oleh hutang, semakin tinggi DER, maka semakin besar jumlah pinjaman yang digunakan untuk menghasilkan keuntungan bagi perusahaan (Raja dan Catur, 2016). 
Penelitian ini didukung oleh Sukarya dan Baskara (2019) yang menjelaskan bahwa leverage berpengaruh positif signifikan terhadap nilai perusahaan. Sama halnya juga dengan penelitian Putri dan Dudi (2019) menjelaskan bahwa leverage berpengaruh positif signifikan terhadap nilai perusahaan.

Sedangkan hasil yang berlawanan ditunjukkan dalam penelitian dari Prastika (2012) yang menyimpulkan bahwa leverage memiliki pengaruh yang tidak signifikan terhadap nilai perusahaan. Penelitian yang sama juga dijelaskan oleh Natalia (2013) yang menyatakan bahwa leverage tidak berpengaruh terhadap nilai perusahaan.

\section{Pengaruh Profitabilitas}

Terhadap Nilai Perusahaan. Berdasarkan variabel profitabilitas nilai t hitung sebesar 19,426 dan nilai t tabel sebesar 2,028 yang berarti nilai t hitung lebih besar dari t tabel $(19,246>2,028)$ dan nilai signifikannya sebesar 0,000, artinya nilai signifikan ini lebih kecil dari 0,05 $(0,000<0,05)$, maka dapat disimpulkan Ha diterima Ho ditolak. Hasil penelitian ini menunjukkan bahwa profitabilitas berpengaruh positif signifikan terhadap nilai perusahaan.

Profitabilitas merupakan rasio untuk menilai kemampuan perusahaan dalam mencari keuntungan (Kasmir, 2012). Berdasarkan laporan keuangan tersebut akan dapat ditentukan hasil analisis sejumlah rasio dan selanjutnya rasio ini digunakan untuk menilai beberapa aspek tertentu dari operasi perusahaan. Analisis profitabilitas bertujuan untuk mengukur kemampuan perusahaan dalam memperoleh laba, baik dalam hubungannya dengan penjualan, assets, maupun modal sendiri. Jadi hasil profitabilitas dapat dijadikan sebagai tolak ukur ataupun gambaran tentang efektivitas kinerja manajemen ditinjau dari keuntungan yang diperoleh dibandingkan dengan hasil penjualan dan investasi perusahaan. Profitabilitas dalam perusahaan dapat meningkatkan nilai perusahaan, maka $\mathrm{Ha}$ ditolak. ROA mengukur kemampuan perusahaan dalam menghasilkan laba dengan memanfaatkan total asset yang dimiliki perusahaan, nilai ROA yang tinggi dapat memberikan dampak positif pada peningkatan nilai peusahaan, dengan laba yang tinggi maka tingkat kepercayaan investor juga akan meningkat, hal tersebut berdampak pada nilai perusahaan yang akan meningkat (Raja dan Catur, 2016).

Penelitian ini didukung oleh Putri dan Dudi (2019) menyatakan bahwa profitabilitas berpengaruh positif dan signifikan terhadap nilai perusahaan. Sama halnya juga dengan penelitian Irma dan Christy (2018) menjelaskan bahwa profitabilitas berpengaruh signifikan terhadap nilai perusahaan.

Sedangkan hasil yang berlawanan ditunjukkan dalam penelitian yang dilakukan oleh Hermawan dan Maf'ulah (2014) yang menjelaskan bahwa profitabilitas tidak dapat mempengaruhi nilai perusahaan.

\section{SIMPULAN}

Kesimpulan. Berdasarkan hasil analisis yang telah di uraikan dalam bab sebelumnya dapat disimpulkan sebagai berikut :

1. Likuiditas tidak berpengaruh terhadap nilai perusahaan pada perusahaan makanan dan minuman yang terdaftar di Bursa Efek Indonesia tahun 2015-2018.

2. Leverage berpengaruh positif signifikan terhadap nilai perusahaan pada perusahaan makanan dan minuman yang terdaftar di Bursa Efek Indonesia tahun 2015-2018.

3. Profitabilitas berpengaruh positif signifikan terhadap nilai perusahaan pada perusahaan makanan dan minuman yang terdaftar di Bursa Efek Indonesia tahun 2015-2018.

4. Likuiditas (X1), leverage (X2) dan profitabilitas (X3) secara simultan berpengaruh signifikan terhadap nilai perusahaan (Y) pada perusahaan makanan dan minuman yang terdaftar di Bursa Efek Indonesia tahun 2015-2018.

\section{Saran}

Hasil Penelitian. Di lihat dari hasil olah data menunjukkan bahwa nilai likuiditas 
tidak berpengaruh terhadap nilai perusahaan, agar nilai likuiditas dapat berpengaruh salah satunya dengan cara menaikkan asset lancar yang dimiliki perusahaan. Karena semakin tinggi nilai likuiditas maka semakin tinggi nilai perusahaan yang tercermin dari harga saham.

Bagi Investor. Hasil penelitian ini dapat dilihat bahwa variabel profitabilitas sangatlah berpengaruh terhadap nilai perusahaan. Investor disarankan sebaiknya lebih melihat profitabilitas perusahaan, karena semakin tinggi nilai ROA dalam perusahaan maka tinggi pula laba yang didapat dalam perusahaan sehingga dapat lebih menguntungkan bagi para investor

Bagi Peneliti. Sebaiknya penelitian selanjutnya dapat memperluas obyek penelitian selain perusahaan makanan dan minuman, tahun yang berbeda dan variabel lainnya atau yang lebih dari tiga variabel independen yang dapat dipergunakan untuk menyempurnakan penelitian, misalnya variabel kebijakan dividen.

\section{DAFTAR PUSTAKA}

Aniela, Nurminda, dkk. (2017). Pengaruh Profitabilitas Leverage, dan Ukuran Perusahaan Terhadap Nilai Perusahaan Studi Perusahaan Manufaktur Sub Sektor Barang dan Konsumsi Yang Terdaftar di BEI Periode 2012-2015.

Kasmir. (2012), Analisis Laporan Keuangan. Jakarta : PT. Raja Grafindo Persada.

Elianah, dkk. (2014). Pengaruh Sistem Akuntansi Manajemen dan Audit Internal Terhadap Manajerial Kinerja.

Fakhrana, Oktaviani. dkk. (2019). Pengaruh Profitabilitas, Likuiditas, Leverage, Kebiajkan Dividen, dan Ukuran Terhadap Nilai Perusahaan (Studi Empiris Perusahaan Sektor Real Estate, Properti, dan Konstruksi Bangunan yang Terdaftar di Bursa Efek Indonesia Tahun 2014-2016).

Harahap, Sofyan Syafri. (2009). Analisis Kritis Laporan Keuangan. PT Rajawali Pers. Jakarta.
Harjito, Agus dan Martono. (2011). Manajemen Keuangan. Edisi Kedua, Cetakan Pertama, Penerbit Ekonosia, Yogyakarta.

Henny, Rahyuda Ni Kadek Sirma, Nila Sucipta. (2015). Pengaruh Pertumbuhan Perusahaan Likuiditas dan Maturity Terhadap Peringkat Obligasi Perusahaan di BEI. E-Journal Manajemen Vol. 14 No.3. Hery. (2017). Kajian Riset Akuntansi. Penerbit PT Grasindo, Jakarta.

Sukarya, I Gde dan Kajeng Baskara. (2019). Pengaruh Profitabilitas, Leverage, dan Likuiditas Terhadap Nilai Perusahaan Sub Sektor Food And Beverages.

Indrianto, Nur dan Bambang, Supomo (1999). Metodologi Penelitian Bisnis Untuk Akuntansi Manajemen, Yogyakarta: BPFE.

Irma, Desmi Awulle, dkk. (2016). Pengaruh Likuiditas Solvabilitas dan Kepemilikan Institusional Terhadap Nilai Perusahaan Food dan Beverage Yang Terdaftar di Bursa Efek Indonesia Periode 2012-2016.

Kasmir. (2016). Analisis Laporan Keuangan Edisi 1, Cetakan 9, Jakarta: Rajawali Pers.

Nurhayati, M. (2013). Profitabilitas, Likuiditas dan Ukuran Perusahaan Pengaruhnya Terhadap Kebijakan Dividen dan Nilai Perusahaan Sektor Non Jasa. Jurnal Keuangan dan Bisinis. PP 65-80.

Prasetyorini, Bhekti Fitri. (2013). Pengaruh Ukuran Perusahaan Leverage, Price, Earning Ratio dan Profitabilitas Terhadap Nilai Perusahaan. Jurnal Ilmu Manajemen.

Putri dan Dr. Dudi .(2019). Pengaruh Tingkat Likuiditas, Profitabilitas dan Leverage Terhadap Nilai Perusahaan Pada Sub

Sektor Makanan dan Minuman yang Tercatat di Bursa Efek Indonesia Periode 2010-2017.

Raja, Wulandari Putri dan Catur, Fatchu Ukhriyawati. (2016). Pengaruh Likuiditas, leverage dan Profitabilitas Terhadap Nilai Perusahaan Pada Perusahaan Telekomunikasi yang Terdaftar di BEI Tahun 2012-2014.

www.finance.detik.com

www.idx.annual.statistics-2015-2018

www.iqplus.info 